\title{
THE IMPACT OF SOCIAL STIGMA AND DEPRESSION ON THE QUALITY OF LIFE OF PEOPLE LIVING WITH HIV/AIDS IN PEMATANGSIANTAR
}

\author{
Betty Saurina Mariany
}

Masters Program in Public Health, Universitas Sumatera Utara

\begin{abstract}
Background: Earlier studies have shown that depressive disorders and symptoms significantly impair functioning in a number of areas, including work functioning, social functioning, and health. This study aimed to examine the impact of social stigma and depression on the quality of life of people living with HIV/AIDS in Pematangsiantar, North Sumatera.

Subjects and Method: This was a cross sectional study conducted in Pematangsiantar, North Sumatera. A sample of 32 people living with HIV/AIDS was selected for this study. The dependent variable was quality of life. The independent variables were social stigma and depression. The data were collected by questionnaire and analyzed by a multiple logistic regression.

Results: Both social stigma $(\mathrm{OR}=0.34 ; \mathrm{p}=0.023)$ and depression $(\mathrm{OR}=0.17 ; \mathrm{p}=$ o.048) deteriorated the quality of life of people living with HIV/AIDS.

Conclusion: Both social stigma and depression deteriorate the quality of life of people living with HIV/AIDS.
\end{abstract}

Keywords: HIV/AIDS, social stigma, depression, quality of life.

\section{Correspondence:}

Betty Saurina Mariany. Masters Program in Public Health, Universitas Sumatera Utara, Medan, North Sumatera. Email: betty_mariany@yahoo.com.

Mobile: 081362205391. 